\title{
As mitologias do sertão através do cinema e literatura
}

\author{
The backwood's mythology through movies and literature \\ Thiago de Brito Varjão \\ Universidade Federal de Sergipe. São Cristóvão, Sergipe, Brasil.
}

\begin{abstract}
Resumo: O cinema e a literatura de cordel apresentam o Nordeste como uma feira de mitos com características sui generis no que concerne à cultura popular. O imaginário que cerca a região constitui o Nordeste como sendo a terra das lendas, dos cangaceiros, dos jagunços, dos vaqueiros e líderes religiosos. A partir desse ponto de vista, o Nordeste pode ser encarado como uma construção imagético-discursiva onde se propagam os mais diversos mitos, tipicamente, heroicos gerados em um grupo socioeconômico marginalizado, de proletários arraigados à terra. Nesse cenário, dois personagens fundamentais aparecem constantemente nas histórias populares: o cangaceiro e as figuras santas, beatos e líderes religiosos carismáticos. Dentro do corpus, se procura investigar como se dá o processo de criação desses personagens mitificados bem como a função destes a partir do universo imagético-discursivo do cinema e literatura.
\end{abstract}

Palavras-chave: literatura; cinema; cangaço; mito.

\begin{abstract}
Cordel's movies and literature presents the Northeast as a myth fair with sui generis caracteristics in terms of folk culture. The imaginary which surrounds the region constitutes the Northeast as being the land of the legends, of the cangaceiros, of the jagunços, of the cowboys and religious leaders. From this point of view, the Northeast can be seen as an discursiveimagetic construction where the most diverse myths are spread, myths that are, typically, heroic generated in a marginalized socioeconomic group, of earth attached proletarians. In this scenario, two fundamental characters constantly appear in folk stories: the cangaceiro and the saint figures, the beatified and charismatic religious leaders. Inside the corpus, there's an investigation on how the creation process happens for this mythical characters as well as their function as from the discursive-imagetic universe of movies and literature.
\end{abstract}

Keywords: literature; movies; cangaço; saint; myths.

\section{A invenção do Nordeste}

Ao se debruçar sobre a alegoria que representa o Nordeste surgem imagens e/ou símbolos que definem e/ou induzem a características particulares que se tem sobre a região. Alguns exemplos podem ser citados para explicitar o fato como: a seca do interior, o vaqueiro percorrendo a caatinga, os cangaceiros, fanáticos religiosos, lideres messiânicos, valentões que varam léguas atrás de tirar a ofensa cometida em um forró, os retirantes. Esses são algumas breves paisagens que podem ser utilizados para apontar as imagens que se criam sobre o Nordeste, fartamente encontrados na literatura, música, artes plásticas, cinema.

Nesse cenário, dois personagens fundamentais aparecem constantemente ligados ao imaginário popular e, sobretudo, aos mitos fundadores do Nordeste. Entre estes estão a figura do cangaceiro, que tem como representante maior Virgulino Ferreira da Silva, o Lampião; bem como as figuras santas, beatos e líderes religiosos carismáticos, como: Padre Cícero, Frei Damião, Beato Lourenço e o mais famosos entre todos, Antônio Conselheiro. Esses personagens pululam as histórias, lendas e mitos do Nordeste, sobretudo do Nordeste rural. Assim, faz-se entender que estão cravados dentro do que se pode chamar de uma cultura popular nordestina. Entretanto, há de se fazer ressalvas. E uma pergunta. O Nordeste seria uma invenção? Estes personagens são de suma importância para entender a gênese dos mitos nordestinos, como se fossem órgãos vestigiais indicam a ancestralidade de algo que pode estar fundado pelo tempo, ou serem reflexos de uma realidade sociocultural. 
O ambiente propício para o surgimento dos mitos seriam aqueles em sociedades onde a violência fosse também um pilar, onde a figura do masculino, do coronel, dos bringandage compusessem o espaço das lendas.

\begin{abstract}
Sociedade de relações sociais extremamente violentas, onde uma mitologia do masculino, do macho, se encarnava em figuras como a do coronel, do cangaceiro ou do jagunço. Uma sociedade sacralizada, onde a presença da religiosidade e do misticismo dava origem a manifestações messiânicas e revoltas em torno de dadas crenças e figuras místicas (ALBUQUERQUE JÚNIOR, 2013, p. 20).
\end{abstract}

Vetor dos mitos e lendas que cercam a região e seus personagens, a gesta popular, através dos tempos, proporcionou a difusão das mais diversas lendas, contos e histórias que paulatinamente foram transmitidas via oral. Quase tudo se transformava em uma história, desde o trabalho no campo até as pelejas de grandes cantadores (Peleja de Cego Aderaldo com Zé Pretinho), bichos que se casavam ( $O$ casamento do bode com a raposa), ou de gente que virava bicho ( $A$ moça que bateu na mãe e virou cachorra), até mesmo animais misteriosos que cruzavam o céu de países longínquos como a Grécia $(O$ romance do Pavão Misterioso). Assim, também, sucedeu a respeito dos bravos cangaceiros até santos-vivos que guardavam seu povo até o dia do retorno do Senhor, das assombrações e riquezas em reinos além-mar que seriam distribuídas quando o rei Sebastião retornasse. Tais histórias não são exclusivas do Nordeste, é óbvio, mas, talvez, foi a região onde tais histórias firmaram raízes profundas ao ponto de criar uma identidade que, assentada com o tempo, construíram a ideia do que seja o homem-nordestino.

A princípio a ideia de Nordeste pode ser encarada como uma invenção, de modo a atender grupos políticos que reclamavam ao Estado ajuda no combate às secas (ALBUQUERQUE JÚNIOR, 2011). Outrora, as lideranças políticas falavam em nome de um só povo, uma região unida pelo terror das secas, era esse o panorama. O óbvio deve ser dito, tal medida tinha em vista não a melhora das estruturas, mas o superfaturamento e desvio dos recursos enviados contra as estiagens severas. A seca era um negócio lucrativo, alicerçava uma forte indústria baseada na exploração da miséria.

O termo Nordeste é usado inicialmente para designar a área de atuação da Inspetoria Federal de Obras Contra as Secas (IFOCS), criada em 1919. Neste discurso institucional, o Nordeste surge como a parte do Norte sujeita às estiagens e, por essa razão, merecedora de especial atenção do poder público federal. (ALBUQUERQUE JÚNIOR, 2011, p. 81).
Do ponto de vista histórico, tudo que hoje se configura como sendo Nordeste pertencia ao Norte do Brasil. Falar em Nordeste é algo novo ao se considerar a História do Brasil. Alguns exemplos, retirados da gesta popular, vão exemplificar o argumento. "São os do Norte que vêm!", assim prodigalizava o poeta sergipano Tobias Barreto. Em Os Voluntários do Norte, Manuel Bandeira, em homenagem à Tobias Barreto, insere a frase memorável do poeta sergipano.

Quando o menino de engenho

Chegou exclamando: "Eu tenho,

Ó Sul, talento também!",

Faria, gesticulando, saiu à rua gritando:

- "São os do Norte que vêm!"

[...] E o clamor ia engrossando

Num retumbar formidando

Pelas cidades além...

"Que foi?" as gentes falavam,

E eles pálidos bradavam:

- "São os do Norte que vêm!"

(BANDEIRA, 2005, p. 56-57).

Continuando com os do Norte. Tome-se como exemplo agora alguns trechos da música São os do Norte que vêm (1967), que tem como autoria os músicos Capiba e Ascenso Ferreira e letra de Ariano Suassuna, interpretada por Claudionor Germano. Obra que faz clara referência à Tobias Barreto e ao povo daquela região.

São os do Norte que vêm,

Do sol do céu do sertão,

No couro da minha sela,

No pelo do alazão.

[...] Filho do sol do deserto,

Sou dono do meu destino,

Meu canto é o rifle de ouro,

Que foi de Antônio Silvino.

(CAPIBA; FERREIRA; SUASSUNA, 1967).

Os trechos apresentam uma breve miscelânea que compõe o recorte sobre o Norte (Nordeste). Temos aqui um pequeno e simples dos muitos exemplos que podem ser retirados das mais diversas expressões artísticas. Dessa forma, pode-se apontar para uma afirmativa no sentido de dizer que os personagens supracitados fazem parte de algo que está entranhado dentro da memória cultural, dentro de uma ideia geral da identidade do ser-nordestino. Lugar de engenho, seca, sertão, beatos, terra de valentões ,do povo na feira, das brigas de faca peixeira, dos coronéis, terra de jagunços, dos vaqueiros e cangaceiros. Essa pequena lista sobre os personagens pode ser encontrada facilmente ao se debruçar sobre os estereótipos que formam a pintura que se faz da região, na construção e criação de um espaço mítico endossado pela forma da imagem e do discurso. A 
literatura de cordel, através da poesia popular, endossaria a propagação desses mitos.

\section{O mito imagético-discursivo: Nordestern, folhetes e cordel}

Bazin (2014) ao observar o western diz ser esse um gênero americano por excelência, nele estão incrustrados traços da cultura estadunidense que trazem à tona aspectos de uma época vivida, a chamada Marcha para o Oeste. Se nos Estados Unidos o cowboy representa, no imaginário popular, a figura do herói vestido com chapéu, calça de couro, fivela, esporas e arma em punho, no Brasil, em certa medida, se tem a figura do cangaceiro como representante. O cangaço é um movimento que desde muito tempo é apresentado ao público através do cinema, na década de 20 do século passado já se tem notícia de filmes que abordam o cangaceirismo (VIEIRA, 2007), como, por exemplo, as obras Filhos sem Mãe (1925), dirigido por Tancredo Seabra e Sangue de irmão (1926), dirigido por Jota Soares. Nesse período ainda reinava pelos sertões a figura de Virgulino Ferreira da Silva, o rei do cangaço.

A figura de Lampião está enraizada dentro da memória e cultura popular da região Nordeste, tornandose uma espécie de objeto-fantástico mesmo depois de sua morte, sua vida e saga são imortalizadas na música, na dança (xaxado), nos cordéis, nos contos populares e, também, no cinema. É verdade afirmar, dessa forma, que a imagem de Lampião enraizou-se dentro do imaginário da população ao ponto do fetichismo movido pela veneração à imagem que representa, construído através do modelo de vingador e defensor da justiça, contra a opressão do Estado. A recorrência do tema inspirado nos filmes de Hollywood faz surgir no Brasil o "Nordestern, neologismo criado por Salvyano Cavalcanti de Paiva para caracterizar os filmes brasileiros que tiveram uma forte influência do western norte-americano" (VIEIRA, 2007, p. 21).

Além a influência do western, o cinema de cangaço bebeu da fonte popular dos cordéis, desde os primórdios com autores como Leandro Gomes de Barro e João Martins de Athayde trazem à tona os causos que rondam a cultura popular, temas que vão desde os desafios e pelejas até cangaceiros tornados santos e heróis. O cordel é dividido em ciclos, para Ariano Suassuna ([19--] apud DUARTE et al, [19--]) esses se dividem em: heroico; maravilhoso; religioso ou moral; cômico; histórico; de amor e fidelidade. Para Carlos Alberto Azevedo ([19--] apud DUARTE et al, [19--]) os ciclos se dividem em: utopia; marido $\operatorname{logrado}^{1}$; demônio logrado ${ }^{2}$; bichos que

Tem como tema os casos de traição, o "chifre", o "corno".

Apresentam o diabo ou demônios sendo enganados. falam; erótico da obscenidade; exemplos e maldições ${ }^{3}$; heroico ou fantástico; histórico e circunstancial ${ }^{4}$; amor e bravura; cômico satírico.

A gesta popular do cordel influenciou a construção da ideia dos mitos que surgem com o passar do tempo, apresentando figuras como vaqueiros, cangaceiros, líderes religiosos, entre outros. Afinal, o cordel teria a mesma importância, àquela época, tal qual hoje se tem a TV, rádio e internet, funcionando como um meio de comunicação de fácil acesso onde toda sorte de acontecimentos e eventos eram veiculados, fato se prova com as estrofes a seguir do cordel Sertão de cabra valente e trabalhador [19--], de Ronaldo Dória Dantas, onde se dá conta das múltiplas funções que o cordel exercia socialmente.
O cordel era o jornal
Rádio e televisão
Que já traziam as notícias
Para o povo do sertão
E ali nasceu e cresceu
Amando esta região
([19--], DANTAS, p. 5).

Porém, um nó górdio surge ao se debruçar sobre o cordel. Seria o cordel, assim como é conhecido no Brasil, uma invenção? Um mito criado a partir da cultura portuguesa? Cordel designava, na península ibérica, a literatura popular, quando trazido ao Nordeste recebeu a estampa de Literatura de pobres (BAROJA, 1988 apud CAVIGNAC, 1995). Fortemente ligado ao mundo rural, do sertão mais especificamente, esse tipo de literatura foi pouco a pouco se consolidando como um gênero autônomo.

\begin{abstract}
O vocábulo cordel nunca foi usado no Nordeste. Com mais de meio século e vida até hoje nunca ouvi ninguém falar em cordel, pedir um pedaço de cordel que é palavra provençal. O povo conhece é cordão, que é corda fina, delgada; ou fio, ou barbante. E mesmo que chamasse literatura popular em verso de literatura de cordão a designação permaneceria pejorativa, falsa, depreciativa, desvalorizando seu conteúdo. As revistas são expostas à venda montadas, escanchadas em pedaços de arame, de cordão ou náilon, nas bancas, mas ninguém nunca designou revista como literatura de arame, literatura de cordão, literatura de náilon. (MAIOR, [19--] apud DUARTE et al., [19--], p. 6).
\end{abstract}

Em verdade, o que hoje se chama de cordel antes se chamava folheto ou folhete, estes eram vendidos pelo folheteiro, daí decorre o nome. Os folhetos, geralmente,

\footnotetext{
3 Tratam das pessoas que por ter profanado algo tido como sagrado são punidos exemplarmente ou amaldiçoados.

4 Narram os atos do cotidiano, as notícias, os acontecimentos do dia a dia.
} 
eram histórias impressas em papel tosco e de baixa qualidade, variavam entre 8 e 16 páginas, podendo chegar a 32 e, muito raramente, até 64 páginas, essa última acabou sendo abandonada devido ao tamanho do custo e do desinteresse do público (CAVIGNAC, 1995), afinal a história tinha que ser sucinta e provocar a curiosidade sem mais delongas.

O nordestino - acrescente-se - só materializa sua poesia popular em verso através de folhetos, ou folhetes, da mesma maneira como a literatura erudita é materializada através de livros. De um modo geral, o nordestino desconhece a designação literatura de cordel; todos só conhecem folheto ou folhete, folheteiro (a pessoa que vende o folheto nas feiras e mercados), folhetaria (a tipografia que imprime e vende os folhetos) (MAIOR, [19--] apud DUARTE et al., [19--], p.6).

Márcia Abreu (2006) revisou os equívocos que surgem a partir dos estudos sobre o cordel e o folhete, entre os vários motivos poderiam ser citados a falta de estudos comparativos entre as duas formas, ou a falta de estudos sistemáticos. A origem ibérica não é explicada, apenas surge como uma fonte original, enquanto o que se produz no Brasil seria o espólio da fonte portuguesa.

Apesar de utilizarmos o termo "literatura de cordel" para designar as duas produções, os autores e consumidores nordestinos nem sempre reconhecem tal nomenclatura. Desde o início desta produção, referiam-se a ela como "literatura de folhetos" ou simplesmente, "folhetos". A expressão "literatura de cordel nordestina" passa a ser empregada pelos estudiosos a partir da década de 1970, importando o termo português que, lá sim, é empregado popularmente (ABREU, 2006, p. 17).

O dado novo ao que antes já havia declarado Souto Maior ([19--]) aponta para o surgimento de uma expressão que surge décadas, ou um século, depois de a literatura ser estabelecida na região brasileira. Entretanto, no que tange ao gênero e a forma as duas vertentes seriam diferentes e, sobretudo, ao caráter popular das obras, pois nem todo cordel é ou era popular, o conceito de literatura popular ganha característica no Brasil, com os folhetes. Ao se falar em popular leia-se algo que está à margem da Literatura, algo vulgar ou marginalizado. Sendo assim, o cordel lusitano não poderia ser concebido como uma literatura feita para as classes menos favorecidas, diferente do folhete nordestino.

É correto dissociar "cordel" e "popular", uma vez que tanto autores quanto público dessa literatura não pertencem exclusivamente às camadas populares. [...] A chamada "literatura de cordel" é uma formula editorial que permitiu a divulgação de textos de origens e gêneros variados para amplos setores da população. (ABREU, 2006, p. 23).
Assim, o cordel estaria mais para um gênero editorial (ABREU, 2006) que para um gênero literário, haja vista os padrões estabelecidos para publicação das obras, a imprensa já havia se estabelecido na Europa e esses tipos de publicações seriam mais lucrativas aos editores. O surgimento do cordel está atrelado à história da imprensa bem como a divulgação para o público.

Os editores, sentindo o interesse de amplas camadas da população em tomar contato com conjuntos de textos em circulação no universo letrado, perceberam a possibilidade de comercialização desse material, desde que seu preço fosse acessível - daí a utilização de papel barato, a opção por um pequeno número de páginas, a venda nas ruas - e desde que o texto fosse adaptado para atender as necessidades de um público pouco familiarizado com o estilo e com a estrutura dos textos produzidos pela elite intelectual (ABREU, 2006, p. 25).

Uma das primeiras diferenças básicas que se pode notar a partir dos relatos citados é perceber que o cordel português tem sua base em uma tradição escrita, fruto da imprensa e de um projeto editorial. Já no Brasil, a tradição oral é predominante. Enquanto um se organiza a partir de um ponto de vista linguístico estruturado a partir de uma sintaxe distinta da fala coloquial, sem recorrer aos frequentes apoios na memória como, por exemplo, recorrências sonoras ou ritmos marcados, estes comuns nas disputas de cantadores nordestinos ou dos folhetes que se utilizam com frequência dos versos em sextilhas e septilhas, as mais comuns, essas tendo o segundo, quarto e sexto versos e, respectivamente, segundo, quarto e sétimo versos rimados a fim de facilitar o processo de memorização. "Em uma cultura oral a memória é o único recurso de conservação de produções intelectuais" (ABREU, 2006, p. 87). Outra diferença sensível a ser notada são os enredos das histórias, enquanto tradicionalmente o cordel português narrava histórias de reis, rainhas e cavaleiros, a tradição nordestina é voltada, inicialmente, ao ciclo do gado, os temas mais sugestivos circundariam a vida no sertão, os bois difíceis de pegar no mato, fugas de animais que colocavam à prova as habilidades dos vaqueiros. Em outro tempo as figuras mudariam de cena e os cangaceiros e líderes religiosos populares tomariam conta dos enredos das histórias.

A venda de folhetos geralmente se fazia a partir da leitura oral de trechos dos poemas, a fim de despertar o interesse e atrair a curiosidade do público para a continuação da história. Criava-se assim uma situação próxima à das apresentações orais em que autor e ouvintes encontram-se frente a frente, possibilitando ao público intervir no curso da apresentação. Nos desafios, bem como nas leituras que acompanhavam a venda de folhetos, se alguma "regra" poética era desrespeitada, 
os ouvintes interrompiam, vaiando e protestando até que se fizessem os versos "como deveriam ser". Os ouvintes não teriam, obviamente, como alterar um folheto já impresso, mas sua participação no momento da leitura sinalizaria para o autor suas preferências, o que, por certo, o influenciaria no momento de compor nova história (ABREU, 2006, p. 95).

Para desatar o nó da dúvida que possa ainda pairar sobre a diferença entre as duas formas de expressão artística um breve comparativo pode ser feito. Enquanto no cordel português os autores editavam obras de sucesso e novelas de cavalaria, aqui o que existia eram autorescompositores, ou seja, eles mesmos fabricavam suas próprias histórias e as comercializavam. Aqui os autores pertenciam às classes populares, apresentando o fruto de seu trabalho em feiras e eventos ao ar livre, enquanto o cordel português se dirigia a grupos sociais distantes da plebe. No Brasil as obras guardam forte tradição oral; lá, sobretudo, se baseavam em fontes escritas. Os temas dos folhetos, geralmente, eram coisas que se passavam em sua própria comunidade, o cotidiano da população rural; já o cordel se pautava na vida dos nobres e histórias da cavalaria. Enquanto o proprietário do folheto era o autor; lá as produções eram de caráter público (ABREU, 2006) e dependiam de editoras.

A vida nordestina parece ser o palco e a fonte dos folhetos. Embora não haja restrições temáticas, essa produção sempre esteve fortemente calcada na realidade social na qual se inserem os poetas e seu público, desde as primeiras produções. Mais da metade dos folhetos impressos nos primeiros anos continha "poemas de época" ou "de acontecido", que tinham como foco central o cangaceirismo, os impostos, os fiscais, o custo de vida, os baixos salários, as secas, a exploração dos trabalhadores (ABREU, 2006, p. 119-120).

Existem diferenças explicitas entre as características das duas formas. Não há uma data clara que possa definir quando e onde um termo sobrepôs o outro, porém o que se sabe é que o nome cordel se popularizou, dessa forma, se tornou palavra corrente para definir as histórias penduradas em barbantes. Fato se prova ao observar duas das mais importantes instituições que abrigam o acervo de folhetos no Brasil, a Fundação Casa de Rui Barbosa e a Academia Brasileira de Literatura de Cordel. Em ambas as instituições o folheto é caracterizado como cordel. O folheto nada mais é que a tradição popular de contar histórias em versos, assim também afiança a Fundação Casa de Rui Barbosa, que define como literatura popular em verso.

Dessa forma, pode se dizer que a invenção do cordel (folhete nordestino) foi absorvida e o termo foi incorporado dentro da cultura do Nordeste. Nesse sentido, faremos a opção pelo uso da palavra cordel à literatura popular em verso ou folhete, haja vista ser uma palavra geradora de identidade. A identidade do cordel incorpora a ideia e os materiais culturais do Nordeste (ALBUQUERQUE JÚNIOR, 2013). "A poesia popular dos cantadores deixa de ser uma manifestação cultural popular sertaneja para ser uma manifestação cultural popular nordestina" (ALBUQUERQUE JÚNIOR, 2013, p. 94).

Já o cinema, desde os primórdios, bebe da fonte da literatura, afinal a formação dos primeiros cineastas era essencialmente literária. Adaptações e releituras de obras clássicas são facilmente percebidas pelo público desde obras clássicas como Fausto, de Goethe, até os contos fantásticos dos Irmãos Grimm. No Brasil, cineastas como Paulo Gil Soares, João Batista de Andrade, Geraldo Sarno e Glauber Rocha evocaram a literatura de cordel como forma de compor suas obras, este último incorporou a estética do universo do cordel no Cinema Novo, Deus e o diabo na terra do sol (1963) e $O$ dragão da maldade contra o santo guerreiro (1969) sem dúvida representam bem essa imagem. Muito embora o cordel seja uma literatura de tradição oral por algum tempo, entre as décadas de 1940 e 1950 do século passado, introduziu fortemente temas e personagens conhecidos do público do cinema, sobretudo nas capas, pois era um atrativo aos compradores (DEBS, 2014). As ilustrações estampando estrelas de Hollywood enriqueceram as ilustrações,

A divulgação dos filmes norte-americanos nos anos $1940 / 50$ e o lado glamoroso das estrelas hollywoodianas explicam a presença de casais míticos ou de mulheres fatais nas capas dos romances. [...] De fato, se considerarmos a importância da imagem da capa do folheto para um público a princípio rural, não é de surpreendente constar a fascinação exercida pelos clichês de atores de cinema (DEBS, 2014, p. 17-18).

Existem alguns motivos para que tal empreendimento fosse tomado, o primeiro se marca pelo ponto de vista financeiro, o baixo custo para anuncio dos filmes facilitava a compra do material; o segundo pela rapidez, pois não necessitaria a confecção das xilogravuras, utilizadas inicialmente, ou de desenhos; o motivo seguinte seria a ligação entre as histórias contadas nos cordéis com suas respectivas capas, imagens de atores e atrizes conhecidos pelo público (DEBS, 2014). Não é de se espantar que se encontre John Wayne, Joan Crawford, Randolph Scott, até mesmo artistas nacionais como Vicente Celestino e Milton Ribeiro, estampando as capas dos cordéis. Quanto ao corpus, é difícil definir quantos cordéis e quais autores abordaram ou inseriram temas ligados ao cinema, sem contar os que fazem referências indiretas ao tema. Porém, 
a estudiosa no tema Sylvia Debs (2014) categoriza os cordéis que se inspiram no cinema em cinco fases: cordéis consagrados a um diretor ou a um ator de cinema, cordéis inspirados em filmes, cordéis que foram concebidos como roteiros de filmes, cordéis que foram adaptados para o cinema e, por fim, cordéis que fazem alusão ao cinema. O cineasta Glauber Rocha mergulhou no universo do cordel e se utilizou desta arte para compor aquelas que, talvez, sejam suas duas maiores obras Deus e o diabo na terra do sol (1963) e $O$ dragão da maldade contra o santo guerreiro (1969), essas influenciadas pelas obras dos cordelistas José Pachêco e Gonçalo Ferreira da Silva, e autores como Guimarães Rosa e José Lins do Rego. Glauber utilizava o cordel como fonte estética, em um modelo

de representação do sertão (seca, cangaço e misticismo) quer seja visualmente (uma fotografia inspirada na xilogravura), do ponto de vista do gestual dos atores, de um ponto de vista musical, temático ou ainda narrativo, a influência do cordel é onipresente: ela traduz a imersão do cineasta nesse universo desde menino (DEBS, 2014, p. 23).

Em O homem que virou suco (1980), do diretor João Batista de Andrade, dialoga francamente com os mitos até aqui apresentados. O cordelista Deraldo ${ }^{5}$ se vê em apuros na cidade de São Paulo por não possuir os "documentos" para comercio de seus cordéis, ao sofrer vários revezes Deraldo, em sonho, se mitifica na figura de um cangaceiro. A alegoria representa o homem nordestino que vai para o Sul ganhar a vida, não conseguindo se vê entre o povo como um estrangeiro, tal quais os cangaceiros eram vistos pela sociedade, pessoas à margem de todas as possibilidades. Segundo o próprio Deraldo a obra $O$ homem que virou suco, cordel criado por ele próprio e vendido em praça pública, é a história de todo nordestino que vai para São Paulo ganhar a vida.

Nesta última obra o cangaço surge como imagem frente ao discurso que sugere a segregação do homem do campo vindo do nordeste que se vê perdido em um contexto urbano, o cangaceiro é a figura antagônica ao progresso que surge em São Paulo, a construção do metrô dependia do homem civilizado, aquele adaptado a aceitar ordens, aquele que não está de acordo está à margem da sociedade e contra o progresso, ou seja, um cangaceiro como é sugerido no vídeo apresentados pela empresa aos funcionários do metrô.

Outro diretor se faz importante citar. No final dos anos 1960 do século passado, surge um grupo encabeçado pelo produtor Thomas Farkas que tinha o intuito de

\footnotetext{
A escolha do diretor não foi por acaso, afinal Deraldo faz alusão ao renomado poeta popular cearense Aderaldo Ferreira de Araújo, mais conhecido como Cego Aderaldo.
}

filmar cenas do Nordeste rural, o projeto foi batizado de Caravana Farkas. Tendo envolvimento com o Cinema Novo, a Caravana Farkas surge em meio ao golpe militar e abarcou temas que envolviam a cultura popular brasileira, fundamentalmente da cultura nordestina do sertão. Não é difícil imaginar que personagens como cangaceiros, repentistas, cordelistas, vaqueiros, santos façam parte do repertório de imagens que constituem os documentários. Entre os títulos temos alguns de grande valor para sustentar a ideia que o mito, que representam os personagens, forja a imagem do Nordeste. A título de ilustração se tem as obras: Memórias do cangaço (1964), que narra uma série de entrevistas com o coronel José Rufino, aquele que matou o cangaceiro Corisco; O homem de couro (1970), apresentando a saga dos vaqueiros nordestinos, desde suas roupas e costumes até a lida na pega de boi, ambas de Paulo Gil Soares; Vitalino - Lampião (1969), apresenta a vida e obra do mestre Vitalino e como o cangaço e Lampião influenciam a confecção de suas peças; Jornal do sertão (1970), documentário que trata da criação do cordel, o modo de produção, os versos, o poema narrativo; Os imaginários (1970), apresentando a materialização das imagens de personagens, assim, imagens de barro e madeira de santos e cangaceiros eram demanda crescente, muito em vista por conta do turismo; Padre Cícero o patriarca de Juazeiro (1972), conta a história do famoso padre cearense, sua vida, obras e milagres, essas últimas sendo obras de Geraldo Sarno.

Tais personagens moldam o que se pode chamar de um modelo obsessivo de representação do Nordeste, ou seja, a partir da imagem que representam através da violência e religiosidade. A imagem cria tipos que são tidos por sua admiração e imitação. Nos documentários citados a coletividade influenciava a criação dos objetos artísticos, ou seja, os bonecos de barro e madeira que eram vendidos. O turismo, por exemplo, até hoje ainda lucra com passeios que retratam as trilhas do cangaço, ou com pôsteres e cartões com suas imagens que são vendidos a preços módicos, artistas e escultores dão vida à memória em suas obras. A criação das obras de arte está atrelada fortemente às imagens que se têm da região.

Dessa forma, o artista popular torna-se interprete da sociedade tradicional da que pertence. E o produto do seu artesanato reflete não apenas o mito trágico criado pela consciência coletiva, mas o próprio destino trágico de toda violência gerada pelo Nordeste tradicional (SARNO; LAMPIÃO-VITALINO, 1969).

O subdesenvolvimento do meio rural e a perpetuação dos mitos também fazem parte da obra do diretor Glauber Rocha, fortemente influenciado pela obra de José Lins do Rego e pela literatura de cordel, o cineasta baiano mergulha no universo do misticismo dos beatos e a 
violência dos cangaceiros aliado à ecologia do sertão. Tal engajamento fez do Cinema Novo um fenômeno nacional. A união de temas da cultura popular lado a lado com a literatura dos regionalistas dos anos 1930 fazem de Glauber Rocha um dos maiores expoentes do cinema brasileiro. O sujeito do discurso é apresentado através das antinomias do cangaceiro e do beato/santo, tomemos como exemplo a obra Deus e o diabo na terra do sol (1964) onde o vaqueiro Manuel ao sofrer os revezes da seca e a violência do patrão transmuta-se em um misto herói social e bandido, enquanto o santo Sebastião é visto como um santo-beato-desvairado. dialoga constantemente com a obra de Glauber, não é de se estranhar que a poesia, essencialmente narrativa, se utilize de recursos retóricos permitindo assim uma carga de densidade dramática, às vezes se aproximando das caricaturas típicas da literatura de cordel. Enquanto que no cordel, costumeiramente, santos e cangaceiros são apresentados como figuras heroicas por excelência, na obra de Glauber Rocha a casca que sustenta essa visão é rompida e dá espaço ao "guerreiro decaído, figura ambígua e esquizofrênica, hesitante entre a perdição e a revelação" (DEBS, 2014, p. 37).

\section{Bandidos, heróis e santos}

Muito provavelmente ao ouvir histórias sobre o cangaço se depara com aquelas em que se coloca o cangaceiro como arauto da justiça, da boa fé, redentor dos mais pobres, em muito se assemelhando ao personagem mítico inglês, Hobin Hood. Ou seja, o fora da lei que emana todas as características de benfazejo que, em armas, enfrenta as crueldades do Estado em meio à seca que castiga as populações sertanejas. O mesmo se dá com a figura do beato cearense Antônio Vicente Mendes Maciel, o Conselheiro. Transformando Conselheiro em uma espécie de enviado de Deus ou um santo vivo. A narrativa oral faz perpetuar e enraizar esses personagens, normatizam a dizibilidade dos acontecimentos, assim, o cangaceiro será o homem de corpo fechado contra todo o mal e os devotos receberão a graça divina quando a hora do fim do mundo se anunciar. Na contramão, é bem verdade que, também, há os relatos extremados onde se dizia que bandos de cangaceiros invadiam vilas e matavam crianças jogando para cima e aparando na ponta de uma faca ou de fanáticos embebidos em um misto de loucura epidêmica ${ }^{6}$ que prestavam orações na esperança do retorno de um rei morto, dando voz a degenerados e toda sorte de anomalias coletivas (RODRIGUES, 2006). O que fica evidente é

\footnotetext{
6 Nina Rodrigues define o arraial como um reduto de degenerados que compactuavam com práticas coletivas perpetuadas através do fanatismo extremado, sendo causado pela mistura das raças e, portanto, sendo os mestiços mais propensos a tais enfermidades. Euclides da Cunha bebe dessa fonte para construir sua obra máxima.
}

o quanto tais temas permeiam a imaginação popular e fazem parte do folclore do nordestino.

A seca é um dos fatores mais importantes pra se compreender o Nordeste e assim se dá na obra de Glauber Rocha. A seca e a cabeça de gado morto é o mote inicial da obra Deus e o diabo na terra do sol (1964). De início se tem apresentado o vaqueiro Manoel que, em breve, se transforma em cangaceiro. A pergunta inicial a se fazer é: como um simples vaqueiro se torna cangaceiro? Responder a essa pergunta com o clichê básico, e não menos verdadeiro, da injustiça sofrida talvez seja a maneira mais simples de se compreender os acontecimentos, mas, também, esconde uma série de problemas que não finda apenas no fato dos personagens se tornarem cangaceiros, pura e simplesmente, pela sede em buscar justiça. A justiça é, sim, um dos fatores, mas está entrelaçada a outros tantos problemas. Evocar apenas a justiça ou vingança é um erro comum. Dentro da perspectiva histórica o cangaço é dividido em três seguimentos: o cangaço meio de vida, o cangaço de vingança e o cangaço de refúgio. Com isso, torna-se mais claro tentar categorizar ou inserir os personagens em um desses tipos, para compreender como se dá a transformação do vaqueiro para o cangaceiro.

Cangaço meio de vida - tipo de maior frequência e expressão como modalidade criminal dentro do quadro geral do cangaço nordestino. É o banditismo de profissão, que tem como principais representantes Lampião e Antônio Silvino. Cangaço de vingança -tipo de ocorrência relativamente menos frequente, embora as suas características de banditismo sertanejamente ético tenham emprestado à imagem genérica do cangaço grande destaque, especialmente literário. Seus principais representantes são Jesuíno Brilhante e Sinhô Pereira. Cangaço-refúgio - tipo de pequena expressão. Diferentemente dos tipos anteriores, este se caracteriza pela riqueza da estratégia defensiva. Como representante máximo, poderíamos apontar o cangaceiro Ângelo Roque (MELLO, 2013, p. 140).

Em Deus e o diabo na terra do sol (1964) o ponto de virada que transforma Manoel, um simples vaqueiro, em um criminoso se dá quando esse vai encontrar o Coronel Morais para receber parte das vacas como pagamento por ter cuidado do rebanho, a partilha. Mas, logo após, fica sabendo que não receberá nada como remuneração, além de ser surrado pelo Coronel. Assim como a obra de Glauber Rocha, o cordel Antônio Conselheiro, o santo guerreiro de Canudos (1977), já apresenta o mito em seu trecho inicial.
[...] Na Bahia apareceu
Um pregador cearense
Que dizia: Quem sou eu?
Sou o emissário divino
Salvador do Nordestino (CAVALTANTE, 1977, p. 1). 
O mito se diz socialmente, sua eficiência se dá na relação na troca com a sociedade. O fator religioso, também, exerce papel de importância na representação dos personagens, o misticismo é um dos elementos constitutivos, muito provavelmente o elemento mais pungente tanto quanto a violência. $\mathrm{O}$ real e o irreal se mesclam dentro do discurso cinematográfico, "O real é imerso, cercado, atravessado e conduzido pelo irreal. O irreal é moldado, determinado, racionalizado e interiorizado pelo real" (MORIN, 2014, p. 189). Um exemplo pode ser dado no trecho a seguir ao se descrever a figura do Conselheiro, sendo esse comparado a outro personagem mítico.

Vestia ele uma túnica
Grosseira de azulão,
De cabeça descoberta
Apoiado num bastão,
Barbas brancas e crescidos
Seus cabelos, parecidos
Semelhantes de Sansão (CAVALCANTE, 1977, p. 2).

Em A chegada de Lampeão no inferno [19--], após entrar à bala no inferno, Lampião provoca uma bagunça no recinto, os assessores do diabo juntam um grupo de pequenos demônios e vão tentar expulsar o bandoleiro, mas, como esperado, o herói-cangaceiro sai vencedor da batalha.

Lampeão é um bandido
ladrão da honestidade
só vem desmoralizar
a nossa propriedade (PACHECO, [19--], p. 4).

Mesmo depois de morto a figura de Lampião se faz presente dentro do imaginário da cultura popular nordestina, as proezas, valentia e destemor são colocadas lado a lado com os casos de crueldade, brutalidade e violência. Um cangaceiro que nem mesmo o diabo suportaria em seu reino. A confusão provocada por Lampião no inferno é tão grande que depois de arrasar o local o cangaceiro vai embora, pois não tem mais com quem brigar. No inferno não ficou, no céu não poderia entrar, só lhe restava voltar para o sertão, lugar de nonada. Universo do cordel onde o real se mescla à figuras do imaginário, todo um simbolismo esta incrustrado nas obras que remontam figuras históricas como: Antônio Conselheiro, beato Lourenço, Padre Cícero, Lampião, Corisco, Antônio Silvino e Jesuíno Brilhante.

O discurso cinematográfico também caminha nesse sentido, em Deus e o diabo na terra do sol (1964) Manoel, antes mesmo de matar o Coronel Morais, já intuía sobre a salvação da alma ao encontrar o Santo Sebastião que perambulava com os romeiros, do mesmo modo se identifica à figura do famoso cangaceiro Corisco. Por outra mão, fica claro que dentro da narrativa cinematográfica os personagens santos são apresentados como figuras desvairadas, doidos varridos que arregimentam uma multidão de outros fanáticos, coadunando com as ideias de Nina Rodrigues e Euclides da Cunha ao observar os movimentos religiosos no sertão baiano. O mesmo se dá em Antônio Conselheiro, o santo guerreiro de Canudos (1977), o fato é atenuado ao dizer que se trata de um fanático, porém um herói.

\author{
Foi Antônio Conselheiro \\ Um bravo heróe [sic], Fanático \\ Um cidadão brasileiro (CAVALCANTE, 1977, p. 8).
}

O cinema e a literatura criam o mito ou uma identidade regional desses tipos, estando enraizados na cultura do Nordeste, seja essa na música, na literatura de cordel ou no cinema (DEBS, 2010). As figuras de cangaceiros e líderes messiânicos se estabelecem dentro de um contexto social, cultural, geográfico e econômico da região.

O mito do herói-cangaceiro e o santo-Conselheiro são alguns exemplos de como os reflexos dos acontecimentos históricos e sociais ainda reverberam mesmo depois de 79 anos da morte de Lampião e 120 anos da queda do arraial do Belo Monte (Canudos). Esses personagens, misto de heróis e anti-heróis, mocinhos e vilões, mesclados, carregam a marca do registro e sua passagem ainda hoje deixam marcas na cultura do Brasil, principalmente do Nordeste.

O mito não está, no entanto, obrigatoriamente contra a história. Ele tanto pode ser usado para remeter a um passado que se quer manter vivo, tornando o presente continuidade de um dado passado que se constrói, como foi o caso dos mitos tecidos pelos tradicionalistas, como pode ser usado para valorizar uma descontinuidade entre o presente e o passado. Quando o mito se humaniza, se encarna na história, faz a história possível; torna a utopia material (ALBUQUERQUE JÚNIOR. 2013, p. 218).

\section{Considerações finais}

Esse trabalho apontou para um caminho onde a narrativa cinematográfica e o cordel constituem a narrativa mitológica, no sentido de dar verossimilhança ao universo do fantástico dos tipos sociais que estão, muitas vezes, à margem da sociedade. O Nordeste, do sertão, é o universo material das lendas que se firmam no imaginário-real de um povo. Terreno onde os personagens fincam estacas no adusto espaço-tempo, onde a memória se faz presente em cada palmilhar de causos. O tema não se encerra, ao 
contrário, há pano para costura de muitas mangas, afinal tanto cinema quanto o cordel estão em franca expansão, bem verdade que o primeiro pela facilidade de acesso se faz mais presente contemporaneamente, mas não se deve excluir o papel ou a função do cordel como agente criador e propagador de ideias. O cordel se reinventa, cria novos mitos, novas lendas, novos valores e tradições emergem desse universo. O cordel fornece a linguagem e o código necessários à manutenção da produção artística. Há que pregue que o cordel é um paciente na UTI respirando por aparelhos, em que o fim está próximo, gerando uma espécie de apelo caduco, fomentado pela síndrome do resgate, cujo papel é transformar o que já é um significado em um suposto significante. A síndrome do resgate pode ser entendida como o apelo em que a voz do especialista ou do agente cultural tem o poder de fazer reviver algo que estava morto, sendo assim capaz de apagar mudanças e transformações ocorridas no tempo e por conta do passar do tempo. A síndrome induz que pode trazer algo de volta com efeito ipsis litteris. Mas, ao contrário do que se possa pensar, o cordel não está morto, nem agonizando em uma UTI da Literatura, este respira e se reatualiza constantemente dentro da memória e dos costumes antigos e contemporâneos, basta ver as novas produções que abordam os mais diversos temas como, por exemplo, tecnologias da informação, delações premiadas, grandes feitos da ciência, Olímpiadas, reinterpretações de clássicos da Literatura mundial, o feminismo e até mesmo sobre astronomia e o universo. O cordel acompanha as transformações do dia a dia, vivo permanece enquanto existirem as lendas, os causos, a poesia, os homens nas feiras, os cantadores, os cangaceiros, os beatos, os fanáticos, os santos e heróis, a memória, a identidade e a história.

\section{Referências}

ABREU, Márcia. História de cordéis e folhetos. Campinas: Mercado das letras, 2006.

ALBUQUERQUE JÚNIOR, Durval Muniz de. A feira dos mitos: a fabricação do folclore e da cultura popular (nordeste 1920-1950). São Paulo: Intermeios, 2013.

ALBUQUERQUE JÚNIOR, Durval Muniz de. A invenção do Nordeste e outras artes. 5. ed. São Paulo: Cortez, 2011.

BANDEIRA, Manuel. Libertinagem \& Estrela da manhã. Rio de Janeiro: Nova Fronteira, 2005.

BARTHES, Roland. Mitologias. 11. ed. Rio de Janeiro: Bertrand Brasil, 2001. p. 131-176.
BAZIN, André. O que é cinema? São Paulo: Cosac Naify, 2014. p. $237-262$.

CAPIBA; FERREIRA, Ascenso; SUASSUNA, Ariano. São os do Norte que vêm. Intérprete: Claudionor Germano. In: II Festival Internacional da Canção Popular. Rio de Janeiro: Codil, 1967. 1 LP. Lado A. Faixa 2.

CAVALCANTE, Rodolfo Coelho. Antônio Conselheiro: o santo guerreiro de Canudos. Salvador: [s.n.], 1977.

CAVGNAC, Julie. Pour une approche antropologique des formes poétique nordestines (Brésil). Caravelle, n. 65, 1995. p. 119-142. (Les cultures populares em Amérique latine).

DANTAS, Ronaldo Dória. Sertão de cabra valente e trabalhador. [S.1.: s.n.], [19--].

DEBS, Sylvie. Cinema e cordel: jogo de espelho. Fortaleza: Interarte Editora/Lume Filmes, 2014.

DEBS, Sylvie. Cinema e literatura no Brasil - os mitos do sertão: emergência de uma identidade nacional. Fortaleza: Interarte, 2007.

DUARTE, Manuel Florentino et al. Literatura de cordel (1 Antologia). São Paulo: Global Editora, [19--].

MELlO, Frederico Pernambucano de. Guerreiros do Sol: violência e banditismo no Nordeste do Brasil. 5. ed. São Paulo: A Girafa, 2013.

MORIN, Edgar. O cinema ou o homem imaginário: ensaio de antropologia sociológica. São Paulo: Realizações, 2014.

PACHECO, José. A chegada de Lampeão no inferno. [S.1.: s.n.], [19--].

RODRIGUES, Nina. As coletividades anormais. Brasília: Edições do Senado Federal, 2006. v. 76. p. 41-56.

VIEIRA, Marcelo Dídimo de Souza. O cangaço no cinema brasileiro. $418 \mathrm{f}$. Tese (Doutorado em Multimeios) - Instituto de Artes: Universidade Estadual de Campinas: São Paulo, 2007.

\section{FILMOGRAFIA}

DEUS e o diabo na terra do sol. Direção: Glauber Rocha. Rio de Janeiro: Copacabana Filmes, 1964. 1 filme (125 min.), $35 \mathrm{~mm}, \mathrm{p} \& \mathrm{~b}$.

LAMPIÃO-VITALINO. Direção: Geraldo Sarno. São Paulo: Saruê Filmes, 1969. 1 filme (9 min), $16 \mathrm{~mm}$, p\&b.

O HOMEM que virou suco. Direção: João Batista de Andrade. Santos. Santos; São Paulo; Rio de Janeiro: Raíz Produções Cinematográficas; Embrafilme - Empresa Brasileira de Filmes S.A.; Governo do Estado de São Paulo - Secretaria de Cultura, 1980. 1 filme (97 min), $35 \mathrm{~mm}$, COR.

Recebido: 01/07/2018

Aprovado: 25/09/2018

THIAGO DE BRITO VARJÃO <thiagobr.varjao@yahoo.com.br> Universidade Federal de Sergipe. 